\title{
DISTRIBUSI UKURAN IKAN MADIDIHANG, CAKALANG DAN LAYANG YANG TERTANGKAP DENGAN PUKAT CINCIN DI PERAIRAN PACITAN JAWA TIMUR
}

\section{FISH SIZE DISTRIBUTION OF YELLOWFIN, SKIPJACK AND FLOAT PURSE SEINE CAUGHT IN THE WATERS PACITAN OF EAST JAVA}

\author{
Helman Nur Yusuf*1, Ronny Irawan W², Budhi HS Iskandar ${ }^{2}$ dan Deni A. Soeboer ${ }^{2}$ \\ ${ }^{1}$ Balai Riset Perikanan Laut \\ Jl. Raya Bogor Km 47 \\ ${ }^{2}$ Fakultas Perikanan dan Ilmu Kelautan, IPB \\ Jl. Raya Dramaga Kampus Bogor 16680 \\ E-mail: helmankkp183@gmail.com
}

(Diterima: 12 Maret 2019; Diterima setelah perbaikan: 13 Juni 2019; Disetujui: 14 Juni 2019)

\begin{abstract}
ABSTRAK
Ikan pelagis yang tertangkap pukat cincin dengan ukuran mata jaring 3,81 cm dan 4,46 cm memperlihatkan sebaran dan ukuran jenis ikan yang berbeda. Tulisan ini bertujuan untuk mengetahui kedalaman renang dan sebaran ukuran ikan madidihang, cakalang dan layang yang tertangkap pukat cincin di perairan Pacitan. Penelitian dilakukan selama 2 trip pada bulan Oktober dan Desember 2013. Analisa data yang digunakan adalah selektivitas celah pelolosan pada pukat cincin mengunakan model Holt. Hasil penelitian diperoleh rata-rata ikan yang tertangkap pada ukuran mata jaring 3,81 cm sebesar 33,74 untuk ikan madidihang $33,74 \mathrm{~cm}$, cakalang 49,5 cm dan layang $23,5 \mathrm{~cm}$. Sedangkan pada ukuran mata jaring 4,46 cm untuk madidihang $37,34 \mathrm{~cm}$, cakalang $52 \mathrm{~cm}$ dan layang $29,5 \mathrm{~cm}$. persamaan regresi antara ikan madidihang $Y=0,697 \mathrm{x}-2,477$ nilai $\tilde{a}^{2}=0,933$, ikan cakalang $=0,611 \mathrm{x}-2,758$ nilai $\tilde{a}^{2}=0,922$ dan ikan layang $Y=$ $1,358 \mathrm{x}-4,241$ nilai $\tilde{a}^{2}=0,954$. Terdapat selektivitas optimum yang berbeda pada ukuran mata jaring 3,81 $\mathrm{cm}$ dan $4,36 \mathrm{~cm}$ yang tertangkap.
\end{abstract}

KATA KUNCI: Pukat cincin; sebaran ikan; Pacitan

\begin{abstract}
The Pelagic fish caught by purse seine mesh sizes of $3.81 \mathrm{~cm}$ and $4.46 \mathrm{~cm}$ showing the distribution and size of different species of fish. This paper aims to determine the depth of the pool and fish size distribution yellowfin, skipjack and float purse seine caught in the waters of Pacitan. The study was conducted during two trips in October and December 2013. Analysis of the data used is the selectivity gap for passage of the purse seine using models Holt. Results showed the average fish were caught in the mesh size of $3.81 \mathrm{~cm}$ by 33.74 to $33.74 \mathrm{~cm}$ fish yellowfin, skipjack $49.5 \mathrm{~cm}$ and $23.5 \mathrm{~cm}$ overpass. While the mesh size of $4.46 \mathrm{~cm}$ to $37.34 \mathrm{~cm}$ yellowfin, skipjack $52 \mathrm{~cm}$ and $29.5 \mathrm{~cm}$ overpass. regression equation between fish yellowfin $\mathrm{Y}$ $=0,697 \mathrm{x}-2,477$ value $\tilde{2} 2=0.933$, tuna $=0,611 \mathrm{x}-2,758$ ã $2=0.922$ and the value of fish float $\mathrm{Y}=$ $1,358 \mathrm{x}-4.241$ value $\tilde{2} 2=0.954$. There are different optimum selectivity of the mesh size of $3.81 \mathrm{~cm}$ and $4.36 \mathrm{~cm}$ were caught.
\end{abstract}

KEYWORDS: Purse seines; fish distribution; Pacitan

\section{PENDAHULUAN}

Samudera Hindia merupakan salah satu perairan yang potensial menghasilkan ikan pelagis besar seperti cakalang, tongkol, madidihang, tuna dan pelagis kecil seperti layang biru, kembung, tembang, sunglir dan ikan lemuru. Daerah penyebaran ikan pelagis di Indo-

\footnotetext{
\# Korespondensi: Balai Riset Perikanan Laut
}

E-mail: helmankkp183@gmail.com nesia meliputi perairan barat Sumatera, selatan Jawa, Laut Banda, Nusa Tenggara, Laut Sulawesi dan perairan utara Papua. Secara vertical, penyebaran ikan pelagis dipengaruhi oleh suhu, densitas, kedalaman lapisan termoklin, arus,sirkulasi massa air, oksigen dan kedalaman renang (swimming layers). Pranata (2013) secara umum ikan tuna yang tertangkap diduga pada kedalaman (swimming layer) 64-232 meter. Nugraha 
\& Triharyuni (2009), penyebaran ikan tuna albakora pada kisaran suhu $14-24^{\circ} \mathrm{C}$, dimana saat juvenile tuna albakora berada di wilayah equator dan lapisan renangnya dilapisan dekat permukaan dan setelah berukuran dewasa $(>95 \mathrm{~cm})$ mulai berpindah ke lapisan yang lebih dalam. Lebih lanjut (Block dan Stevens 2001) menyatakan bahwa Tuna madidihang diduga tertangkap pada kedalaman sekitar 64-205 meter dan umumnya pada kedalaman 100 meter yang memiliki cukup kandungan oksigen, sedangkan juvenile sering dijumpai bergerombol dengan cakalang, tuna mata besar dilapisan permukaan dan setelah dewasa berada pada kisaran suhu $18-31^{\circ} \mathrm{C}$. Hasil penelitian Ming et al. (2009) menunjukkan bahwa di Samudra Atlantik Tengah kedalaman renang optimal, suhu air dan kisaran salinitas tuna sirip kuning ditemukan 150,00-179,99 m, 13,00-13,99 !, 35,4035,49 masing-masing. Kedalaman berenang umum, suhu air dan kisaran salinitas adalah 120,00-209,99 m, 12,00-14,14 !, 35,20-35,49.

Distribusi vertikal ikan pelagis umumnya dipengaruhi oleh suhu dari kolom air, kedalaman dari swimming layer, dan kekuatan dari gradien suhu pada termoklin (Trump dan Leggette 1980). Umumnya kolom air pada kedalaman kurang darai $100 \mathrm{~m}$ merupakan daerah yang cukup oksigen. Pada kedalaman air yang lebih dalam biasanya mengandung oksigen sangat rendah yaitu sekitar $2 \mathrm{ml} / \mathrm{l}$, sehingga ikan tuna jarang ditemukan. Ikan biasanya bergerombol sesuai dengan ukuran spesies yang sama maupun dengan spesies lain. Penyebaran ikan tuna di perairan merupakan salah satu respon terhadap perubahan suhu. Pola penyebaran suhu secara tidak langsung mempengaruhi tingkah laku ikan tuna (Laevastu dan Hayes, 1981).

Brata et al. (2011) menyatakan bahwa tuna dengan ukuran lebih kecil dari $100 \mathrm{~cm}$ cenderung tertangkap lebih pada level permukaan atau diatas lapisan termoklin sampai kedalaman 200 meter. Kecuali itu, faktor lingkungan perairan sekitarnya akan mempengaruhi penyebaran ikan pelagis secara horisontal dan vertikal (Allain et al., 2005). Selanjutnya Sulaiman (2006) menyatakan penangkapan dengan alat bantu cahaya dapat mengumpulkan ikan terutama pada kisaran kedalaman antara 20-30 m dan 5-10 m. Lebih lanjut, Gambang et al. (2003) menyebutkan bahwa ikan pelagis kecil umumnya menyebar pada dikedalaman antara $15-60 \mathrm{~m}$. Perbedaan kedalaman ini mengindikasikan jenis dan kedalaman renang ikan berbeda, tergantung dari kondisi optimum yang diperlukan oleh ikan tersebut.

Hasil penelitian Pranata (2013) menyebutkan secara umum ikan tuna tertangkap pada kedalaman (swimming layer) antara 64-232 meter. Lebih lanjut Nugraha
\& Triharyuni (2009) berpendapat bahwa penyebaran ikan tuna albakora terdapat pada kisaran suhu antara $14-24^{\circ} \mathrm{C}$. Saat masih juvenile ikan ini menyukai perairan hangat di daerah equator dengan lapisan renangnya di dekat permukaan. Pada saat dewasa berukuran $(>95 \mathrm{~cm})$ akan beruaya ke lapisan yang lebih dalam (Block dan Stevens 2001). Tuna mata besar tertangkap pada kedalaman antara 64-250 m. Pada ukuran yang lebih besar berada di bawah lapisan termoklin (Suzuki et al., 1977 dalam Santoso 1999). Ikan madidihang diduga tertangkap pada kedalaman antara 64-205 $\mathrm{m}$ dan umumnya pada kedalaman sekitar 100 meter dimana masih memiliki cukup kandungan oksigen. Pada stadia juvenil sering diketemukan bergerombol bersama dengan ikan cakalang di lapisan permukaan dan setelah dewasa berada pada kisaran suhu antara $18-31^{\circ} \mathrm{C}$ (Block dan Stevens 2001).

Wyrtki (1961) mengatakan kedalaman termoklin di Samudera Hindia mencapai 120 meter dan bergerak menuju Selatan yaitu ke daerah arus Equatorial Selatan. Laevastu \& Hayes (1981) menyebutkan bahwa faktor oseanografi berpengaruh nyata terhadap penyebaran ikan pelagis. Distribusi ukuran ikan pelagis yang tertangkap di perairan Pacitan diduga dipengaruhi oleh perbedaan ukuran mata jaring (mesh size) dan ukuran kedalaman pukat cincin yang digunakan. Ukuran mata jaring dan kedalaman jaring dapat menentukan terhadap sebaran ukuran ikan yang tertangkap, hal ini diduga bahwa kedalaman perairan mengidentifikasi sebaran jenis yang tertangkap. Pendugaan ukuran ikan pertama kali tertangkap (Lc) indetik dengan peluang ikan yang tertangkap (probabilitas) dengan $\mathrm{L}_{50 \%}$ pada selektivitas alat tangkap tersebut, dimana setiap ukuran ikan yang tertangkap mewakili ikan yang tertangkap atau ikan yang tidak tertangkap di daerah penangkapan. Dasar pengukuran selektivitas ditentukan dengan kisaran panjang terhadap ikan yang di teliti (Sparred \& Vanema 1999).

Pukat cincin merupakan alat tangkap yang efektif dalam menangkap gerombolan ikan pelagis. Proses pelingkaran alat tangkap dapat meloloskan ikan dari alat tangkap yang relatif besar, baik secara vertikal maupun horisontal (Fridman \& Carrothers, 1986). Tujuan penelitian adalah untuk mendugaan ukuran ikan pertama kali tertangkap di perairan Pacitan diestimasi berdasarkan hasil tangkapan ikan pukat cincin dengan panjang jaring antara 380-420 m, kedalaman 120-136 $m$ dengan ukuran mata jaring kantong $3,81 \mathrm{~cm}$ dan $4,46 \mathrm{~cm}$. Hal ini di teliti karena kurangnya informasi mengenai sebaran rata-rata ukuran pertama kali tertangkap baik secara vertikal dan horisontal menurut kedalaman dengan pukat cincin di perairan Pacitan Jawa Timur. 


\section{BAHAN DAN METODE}

Penelitian dilakukan di perairan Pacitan dan sekitarnya (Gambar 1), pada bulan Oktober dan Desember 2013. Untuk keperluan analisis, data dikumpulkan dari observasi di laut dan observasi di tempat pendaratan ikan dengan bantuan enumerator. Observasi di laut mengunakan alat pukat cincin berukuran $1^{1 / 2}, 2$ dan 3 inci (milik KM. Inka Mina 127) dan alat pukat cincin berukuran $1^{1 / 4}, 2$ dan 3 inci (milik KM. Baruna Jaya 7). Diperoleh 8 sampling setiap kapalnya pada bulan Oktober dan Desember 2013 yaitu pada kondisi bulan gelap dan sedang (tidak gelap). Observasi didarat dilakukan setiap bulan. Data bulanan yang dikumpulkan dari 5 buah kapal meliputi: ukuran panjang cagak ikan target yaitu ikan madidihang (Thunnus albacares), cakalang (Katsuwanus pelamis) dan layang (Decapterus macarellus), serta aspek oprasional (hasil tangkapan per trip dan jumlah setting per trip). Rancang bangun dan ukuran pukat cincin yang digunakan di sajikan pada Gambar 2 dan 3.

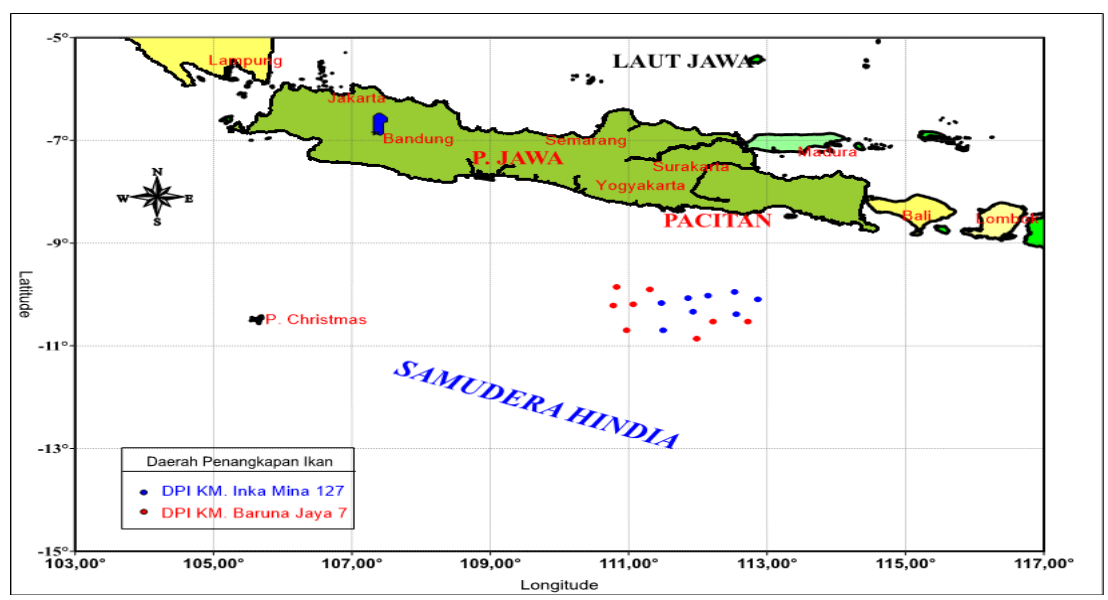

Gambar 1. Peta daerah penangkapan ikan dengan pukat cincin di perairan Selatan Pacitan. Figure 1. Map of fishing ground of purse seine in the South of Pacitan.

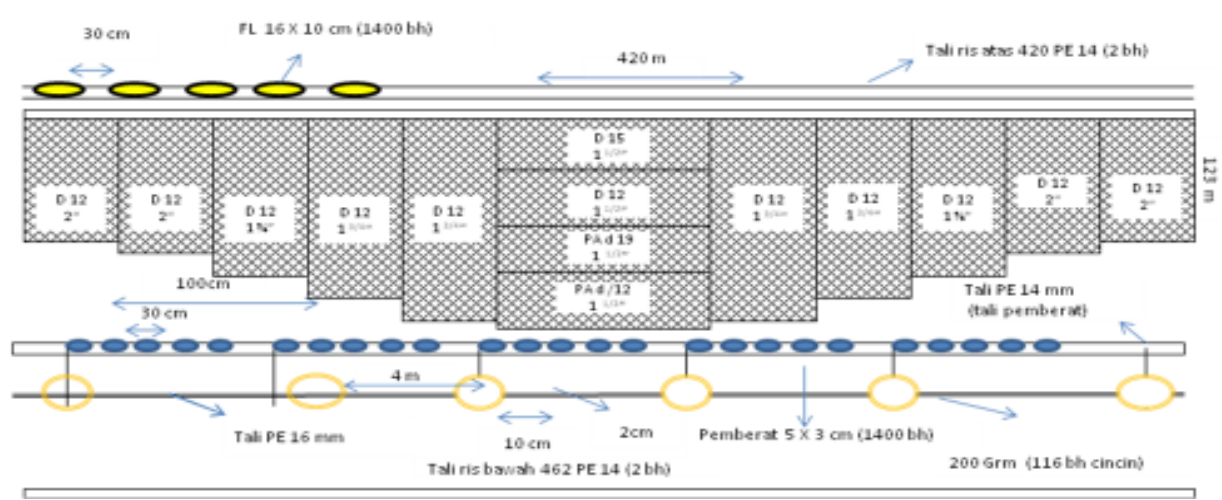

Gambar 2. Spesifikasi pukat cincin milik KM. Inka Mina 127.

Figure 2. Specification of purse seine of MV. Inka Mina 127.

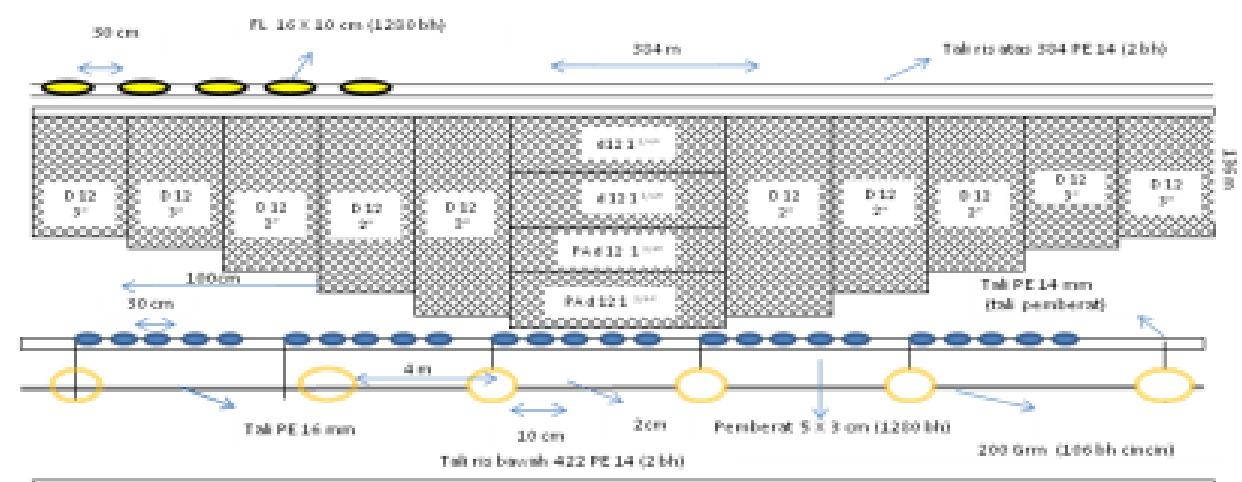

Gambar 3. Spesifikasi pukat cincin milik KM. Baruna Jaya 07.

Figure 3. Specification of purse seine of MV. Baruna Jaya 07. 
Pengukuran panjang cagak ikan atau fork length berdasarkan hasil tangkapan per kapal sampel, dengan ukuran mata jaring yang berbeda, kemudian sampel ikan yang diukur dianalisis menurut kedalaman renang ikan (swimming layers) secara deskriptif dalam bentuk tabel. Proses perhitungan rata-rata ikan pelagis pertama kali tertangkap Lc atau L50\% pada alat tangkap pukat cincin sama seperti pada gillnet yaitu dengan cara dilingkarkan (encircling gillnet and purse seine) yaitu dengan selektivitas pada kelolosan dengan model Holt (1963) dalam Sparre \& Venema (1999) sebagai berikut: Proses analisis terhadap ikan yang tertangkap menurut kelompok panjang untuk masing-masin alat sebagai berikut :

1. Menghitung logaritma rasio y (lingkar tubuh ikan/ girth opercular/go) untuk masing-masing kelompok panjang yang saling tumpang tindih :

$\mathrm{Y}=\mathrm{Ln}\left(\frac{\mathrm{Cb}}{\mathrm{Ca}}\right)$

$\mathrm{Y}=$ frekuensi panjang $(\mathrm{cm})$

$\mathrm{Ca}=$ Jumlah ikan yang tertangkap pada mata jaring $3,81 \mathrm{~cm}$

$\mathrm{Cb}=$ Jumlah ikan yang tertangkap pada mata jaring $4,46 \mathrm{~cm}$

2. Menganalisis regresi logaritma rasio $(y=\ln (\mathrm{Cb} /$ Ca) terhadap titik tengah interval panjang rata-rata ikan yangbtertangkap $(\mathrm{x}=\mathrm{L})$ :

$\operatorname{Ln}\left[\frac{\mathrm{Cb}}{\mathrm{Ca}}\right]=\mathrm{a}+\mathrm{b} * \mathrm{~L}$

a = Jumlah ikan yang tertangkap pada ukuran mata jaring $3,81 \mathrm{~cm}$

$\mathrm{b}=$ Jumlah ikan yang tertangkap pada ukuran mata jaring $4,46 \mathrm{~cm}$

$\mathrm{L} \quad=$ interval panjang ikan (kelas panjang) $(\mathrm{cm})$

3. Menghitung faktor seleksi :

$\mathrm{SF}=\frac{-2 * \mathrm{a}}{\mathrm{b} *(\mathrm{ma}+\mathrm{mb})}$

$\mathrm{SF}=$ faktor seleksi

ma $=$ ukuran mata jaring $3,81 \mathrm{~cm}$

$m b=$ ukuran mata jaring $4,46 \mathrm{~cm}$
4. Menghitung standar deviasi :

$\mathrm{Lma}=\mathrm{SF}^{*} \mathrm{ma}$

5. Menghitung kurva seleksi dengan memasukkan nilai $\mathrm{L}$ ke :

$$
\begin{aligned}
& \mathrm{Sb}(\mathrm{L})=\exp \left[-\frac{(\mathrm{L}-\mathrm{Lmb})^{2}}{2 * \mathrm{~S}}\right]
\end{aligned}
$$

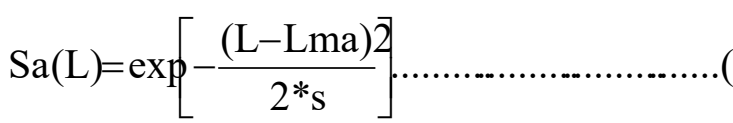

6. Seleksi untuk dua ukuran mata jarring yang berbeda

$\mathrm{S}_{\mathrm{L}}=\exp \left[\frac{-\left(\mathrm{L}-\mathrm{L}_{\mathrm{m}}\right)^{2}}{2 * \mathrm{~s}^{2}}\right]$

$\mathrm{S}_{\mathrm{L}}=$ Ikan dengan kisaran panjang $\mathrm{L}$ tertahan di pukat cincin $\left(0<\mathrm{S}_{\mathrm{L}} \mathrm{d}\right.$ "1)

$\mathrm{L}_{\mathrm{m}}=$ Kisaran panjang optimum ikan yang tertangkap

$\mathrm{S}=$ Standar deviasi dan distribusi normal

$\mathrm{L} \quad=$ interval panjang ikan (kelas panjang) $(\mathrm{cm})$

\section{HASIL DAN PEMBAHASAN}

Jenis ikan madidihang, cakalang dan layang yang tertangkap oleh pukat cincin dengan ukuran mata jaring 3,81 cm rata-rata lebih kecil dibandingkan dengan hasil tangkapan pada pukat cincin dengan mata jaring 4,46 cm pada kedalam sekitar 50 - 120 meter (Tabel 1).

Ikan madidihang dengan kisaran nilai tengah antara 19,5-139,5 cm diperoleh modus 39,5 cm pada ukuran mata jaring $3,81 \mathrm{~cm}$ dan $59,5 \mathrm{~cm}$ pada ukuran mata jaring $4,46 \mathrm{~cm}$. Ikan cakalang dengan kisaran nilai tengah antara $27-87 \mathrm{~cm}$ diperoleh modus $42 \mathrm{~cm}$ pada ukuran mata jaring $3,81 \mathrm{~cm}$ dan $47 \mathrm{~cm}$ pada ukuran mata jaring $4,46 \mathrm{~cm}$. Ikan layang dengan kisaran nilai tengah antara 19,5-37,5 cm diperoleh modus $23,5 \mathrm{~cm}$ pada ukuran mata jaring $3,81 \mathrm{~cm}$ dan $29,5 \mathrm{~cm}$ pada ukuran mata jaring 4,46 cm (Gambar 4). Sebaran ukuran panjang ikan pelagis yang tertangkap berdasarkan ukuran mata jaring $3,81 \mathrm{~cm}, 4,46 \mathrm{~cm}$ menunjukkan adanya perbedaan ukuran ikan. Ukuran ikan yang tertangkap dengan mata jaring $3,81 \mathrm{~cm}$ lebih kecil dibanding ikan dengan mata jaring $4,46 \mathrm{~cm}$ dengan modus yang berbeda. Ikan madidihang yang tertangkap 
dengan modus $39,5 \mathrm{~cm}$ pada ukuran mata jaring 3,81 $\mathrm{cm}$ dan 59,5 cm pada ukuran mata jaring $4,46 \mathrm{~cm}$, ikan cakalang dengan modus $42 \mathrm{~cm}$ pada ukuran mata jaring 3,81 $\mathrm{cm}$ dan $47 \mathrm{~cm}$ pada ukuran mata jaring $4,46 \mathrm{~cm}$ dan ikan layang dengan modus $25,5 \mathrm{~cm}$ pada ukuran mata jaring $3,81 \mathrm{~cm}$ dan $29,5 \mathrm{~cm}$ pada ukuran mata jaring 4,46 cm. Hasil penelitian Martasuganda et al., (2011) menunjukkan kisaran fork length ikan cakalang yang tertangkap dengan jaring insang pada kisaran 36,25-49,91 cm. Collete \& Nauen (1983) fork length ikan cakalang yang tertangkap pada antara 40$80 \mathrm{~cm}$. Bahar et al., (1987) Kisaran panjang cagak ikan cakalang yang tertangkap di Indonesia adalah 18-90 $\mathrm{cm}$, dengan Huhate antara 24-76 em, pukat cincin 35$84 \mathrm{~cm}$, payang $42-69 \mathrm{~cm}$ dan pancing tonda $18-90 \mathrm{~cm}$. Sivasubramanian (1985) di perairan Srilangka dan sekitarnya kisaran panjang cagak ikan cakalang yang tertangkap berkisar $30-78 \mathrm{~cm}$. Collete \& Nauen (1983) Yesaki (1983) menyatakan bahwa ukuran madidihang pertama kalimatang gonad berkisar $53 \mathrm{~cm}$ untuk jantan dan $57 \mathrm{~cm}$ untuk betina di sekitar perairan Philipina, bahkan mencapai 81-100 cm untukbetina di Pasifik sebelah barat.

Tabel 1. Kisaran panjang ikan berdasarkan ukuran mata jaring yang digunakan

Table 1. Range of fish length based on mesh size used

\begin{tabular}{|c|c|c|c|c|c|c|}
\hline \multirow[t]{2}{*}{$\begin{array}{l}\text { Jenis } \\
\text { /Species }\end{array}$} & \multirow[t]{2}{*}{$\begin{array}{l}\text { Jenis Jaring } \\
\text { /Types of nets }\end{array}$} & \multirow[t]{2}{*}{$\begin{array}{c}\mathrm{n} \\
\text { (ekor) }\end{array}$} & \multicolumn{3}{|c|}{$\begin{array}{c}\text { Kisaran panjang }(\mathrm{cm}) / \text { Range } \\
\text { of length }(\mathrm{cm})\end{array}$} & \multirow{2}{*}{$\begin{array}{l}\text { Standar deviasi } \\
\text { /Standard deviation }\end{array}$} \\
\hline & & & $\begin{array}{c}\min \\
(\min )\end{array}$ & $\begin{array}{l}\max \\
(\max )\end{array}$ & $\begin{array}{l}\text { rata-rata } \\
\text { (average) }\end{array}$ & \\
\hline \multirow[t]{2}{*}{ Madidihang } & 1 & 1.295 & 19.5 & 119.5 & 33.74 & 22.0 \\
\hline & 2 & 1.705 & 29.5 & 129.5 & 37.34 & 34.9 \\
\hline \multirow[t]{2}{*}{ Cakalang } & 1 & 1.496 & 27 & 77.2 & 49.5 & 11.6 \\
\hline & 2 & 1.664 & 27.2 & 87.1 & 52 & 11.1 \\
\hline \multirow[t]{2}{*}{ Layang } & 1 & 1.368 & 19.8 & 35,5 & 27.5 & 4.8 \\
\hline & 2 & 1.194 & 21.8 & 37.5 & 29.5 & 4.8 \\
\hline
\end{tabular}

Keterangan/Remarks: $\quad 1$ : jaring ukuran mata $3,81 \mathrm{~cm} /$ net mesh size $3,81 \mathrm{~cm}$ 2: jaring ukuran mata $4,46 \mathrm{~cm} /$ net mesh size $4,46 \mathrm{~cm}$

\#

Madidihang
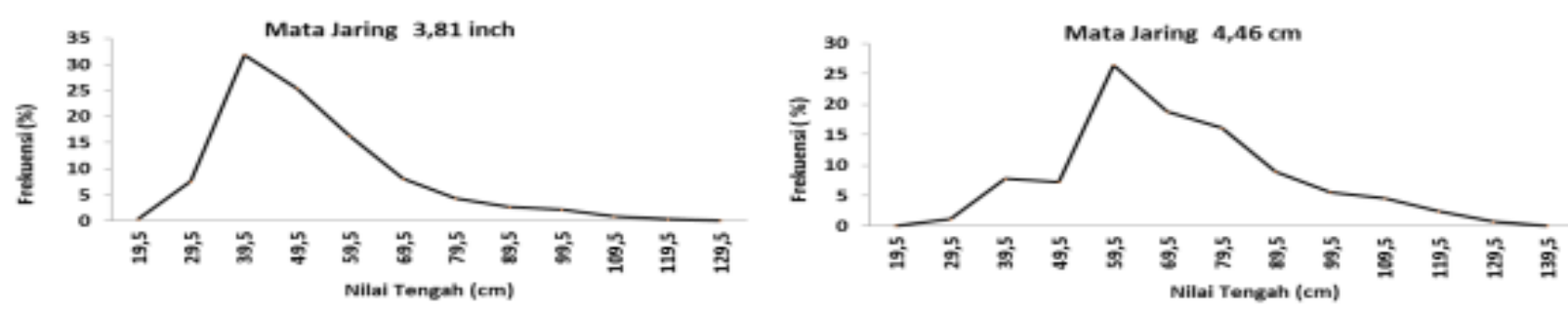

Cakalang
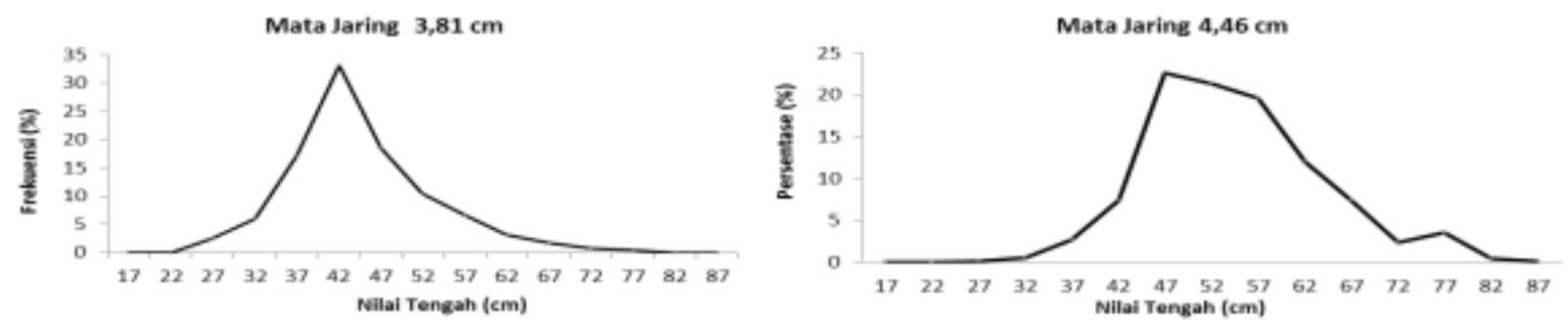

Layang
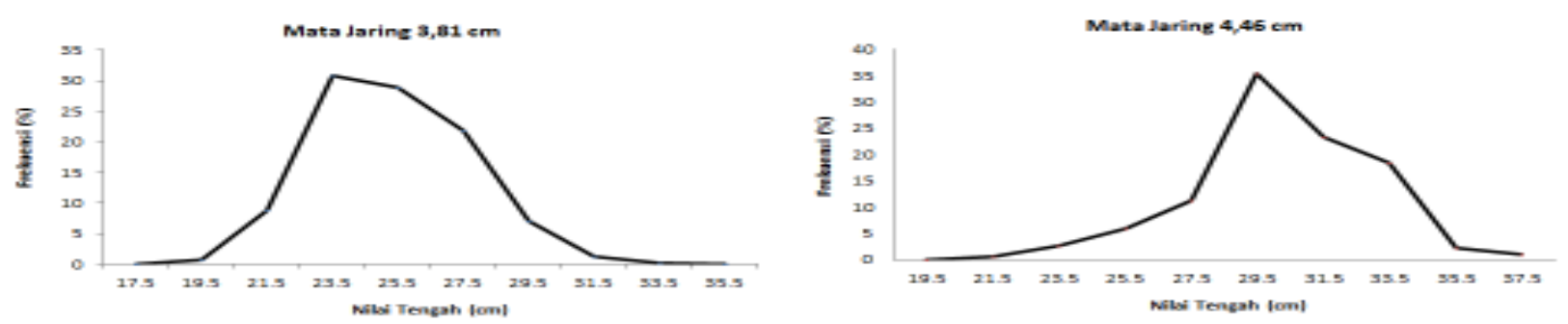

Gambar 4. Persentase sebaran ukuran ikan berdasarkan ukuran mata jaring.

Figure 4 . The percentage of fish size distribution based on mesh size. 
Anggrainy (1991) menjelaskan bahwa Ikan cakalang yang tertangkap dengan handline di perairan Kepulauan Bacan berukuran panjang total antara 31$60 \mathrm{~cm}$, dan 41,6-77,6 cm. (Samad 2002) menjelaskan bahwa kisaran panjang ikan cakalang yang tertangkap dengan handline di perairan Maluku Tengah adalah 40,3$65,4 \mathrm{~cm}$ dan di perairan Kupang adalah 29-58,9 cm dan ukuran dominan 47,0-49,0 cm. Gafa et al., (1987) menjelaskan bahwa ikan cakalang yang tertangkap dengan handline di perairan Sulawesi Tengah berkisar 27,1-57,7 cm. Baso (2011) menjelaskan bahwa ikan cakalang yang tertangkap dengan pole and line di perairan Teluk Bone memiliki ukuran panjang total 14,0-86,0 cm, dengan frekuensi tersebut cakalang di perairan Teluk Bone lebih panjang ibanding dengan perairan lainnya. Syamsuddin et al. (2008) menjelaskan bahwa komposisi ukuran ikan cakalang yang tertangkap di perairan Kupang berkisar 29,0-58,9 cm. LPPT. (2013). Laporan penelitian di wilayah perairan Samudera Hindia selatan Jawa, Bali dan Nusa Tenggara menghasilkan Lc fork length ikan cakalang sebesar $42,89 \mathrm{~cm}$ dan fork length madidihang sebesar 124,16 $\mathrm{cm}$ FL.
Berdasarkan hasil tangkapan jaring pukat cincin, pada kedalaman jaring berkisar 0-121 meter dan 0136 meter mendapatkan hasil tangkapan dengan kisaran panjang ikan layang berkisar anata 19,8-37,5 cm, ikan madidihang berkisar antara 19,5-129,5 cm dan ikan cakalang berkisar antara 17-87 cm. Ukuran ikan pelagis yang tertangkap (Gambar 5), menunjukkan bahwa pukat cincin dengan mesh size $3,81 \mathrm{~cm}$ dapat menangkap ikan madidihang dengan kisaran panjang antara 19,5-119,5 cm dengan nilai Lc sebesar 39,5 cm. Pada mesh size 4,46 cm ukuran ikan madidihang yang tertangkap antara 29,5-129,5 cm dengan nilai Lc sebesar 59,5 cm. Furukawa et al. (2017) bahwa blue fin tuna Pasifik (Thunnus orientalis) umunya berada pada lapisan campuran yaitu pada suhu rata-rata antara 27,6 dan $28,3^{\circ} \mathrm{C}$, sementara studi sebelumnya melaporkan bahwa blue fin tuna Pasifik dengan $\mathrm{FL}>$ $50 \mathrm{~cm}$ di Laut Cina Timur ditemukan paling sering di zona dengan suhu antara 14 dan $19^{\circ} \mathrm{C}$.

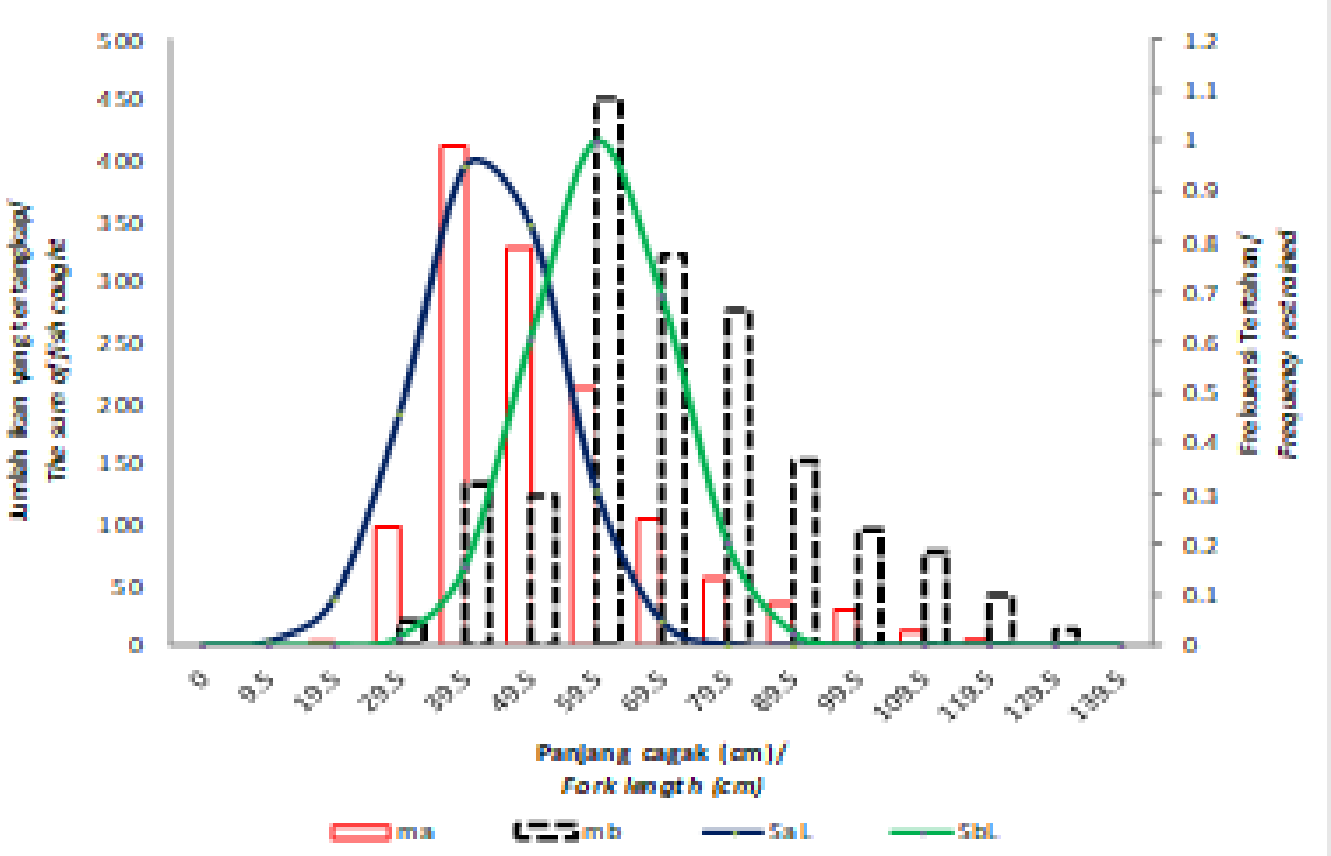

Gambar 5. Kurva selektivitas ikan madidihang pada pukat cincin dengan ukuran mata jaring 3,81 $\mathrm{cm}$ dan $4,46 \mathrm{~cm}$

Figure 5. Selectivity curve of yelloe fin tuna of caught by purse seine with mesh size 3,81 and $4,46 \mathrm{~cm}$

Berdasarkan data tersebut menghasilkan persamaan regresi antara panjang ikan (fork leng) dan titik tengah selang kelas lingkar tubuh ikan pada insang (girth opercular/go) (nilai a =intercept, b = slope) yang tertangap yaitu $Y=0,697 \mathrm{x}-2,477$ (Gambar 6), dengan nilai $\tilde{a}^{2}=0,933$. Persamaan menunjukkan bahwa setiap penambahan panjang ikan madidihang sebesar $1 \mathrm{~cm}$ akan meningkatkan nilai Ln (selektivitas terhadap panjang ikan) sebesar 0,697. Sehingga koefisien korelasinya (ã) sebesar 0,933 yang berarti mempunyai hubungan yang erat sebesar 93,3\%. 
Mertha et al. (2006), menyatakan bahwa ikan madidihang yang tertangkap oleh armada pancing ulur di perairan selatan Palabuhanratu berkisar antara 25$119 \mathrm{~cm}$ dengan modus 45-48 cm. Panjang pertama kali matang gonad ikan madidihang yang tertangkap di Samudera Hindia berada pada kisaran panjang 100$110 \mathrm{~cm}$ atau ikan berumur antara 2,5-3,0 tahun (FAO, 2010). Menurut Sivasubramanium, (1965) dalam Sumadhiharga, (2009) padaumumnya di Samudera
Hindia, ikan madidihang mulai memijah pada panjang cagak $90 \mathrm{~cm}$ atau berumur sekitar 2 tahun. Hasil penelitian Mardlijah \& Patria (2012) bahwa panjang pertama kali matang gonad ikan madidihang betina yang tertangkap di perairan Teluk Tomini adalah 94,8 cm FL. Selanjutnya Zhuetal (2008), memperkirakan ukuran pertama kali matang gonad pada ikan madidihang di Samudera Hindia pada panjang cagak sekitar100 cm.

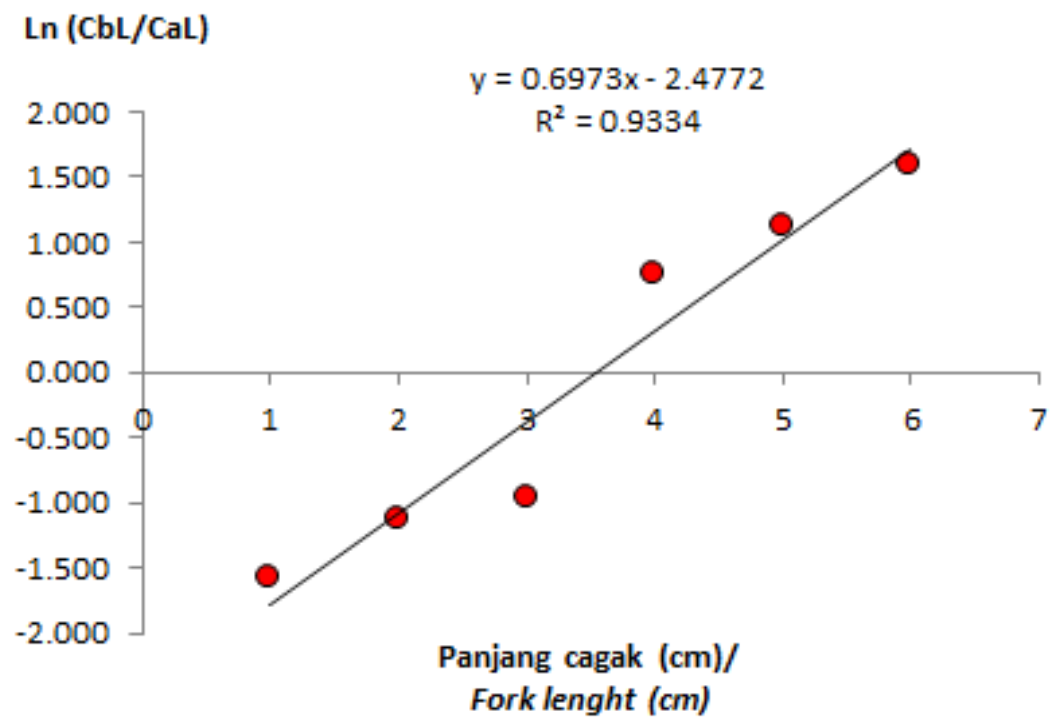

Gambar 6. Regresi dari $\mathrm{L}_{\mathrm{n}}\left(\mathrm{C}_{\mathrm{bL}} / \mathrm{C}_{\mathrm{aL}}\right)$ terhadap panjang ikan madidihang Figure 6. Regression between $\mathrm{L}_{\mathrm{n}}\left(\mathrm{C}_{\mathrm{bL}} / \mathrm{C}_{\mathrm{aL}}\right)$ and length of yellow fin tuna

Hasil penelitian Santoso (1999) tuna mata besar tertangkap pada tertangkap pada kedalaman sekitar 64-250 meter dan tuna mata besar yang lebih besar berada pada di bawah lapisan termoklin. Brata et al. (2011) bahwa ikan jenis tuna madidihang dan albakora tertangkap pada kisaran kedalaman 35,15-299,04 dengan suhu $12,51-26,96^{\circ} \mathrm{C}$, tuna mata besar tertangkap pada kisaran kedalaman 92,23-470,12 meter dengan suhu berkisar $8,35-26,80^{\circ} \mathrm{C}$ sedangkan tuna sirip biru selatan pada kisaran kedalaman 118,23194,21 meter dengan suhu $14,99-22,59^{\circ} \mathrm{C}$. Penelitian Brata et al. (2011) menyebutkan ikan tuna dengan ukuran lebih kecil dari $100 \mathrm{~cm}$ cenderung tertangkap lebih banyak di lapisan termoklin sampai kedalaman 200 meter. Selanjutnya Nishimura (1964) dengan mengunakan echosounder menyebutkan bluefin terdapat pada kedalaman 60-200 meter, madidihang kedalaman 60-120 meter dan albakora pada kedalaman antara 50-80 meter. Song et al. (2008) menyatakan bahwa kisaran optimal kedalaman renang, suhu air, klorofil a dan konsentrasi oksigen terlarut untuk tuna sirip kuning adalah $100,0-179,9 \mathrm{~m}, 15,0-17,9^{\circ} \mathrm{C}, 0,090$ -
0,099 ìg L “ 1, 2,50-2,99 mg L-1, dimana salinitas memiliki pengaruh yang lebih kecil terhadap distribusi vertikal tuna yellowfin dewasa; dan bahwa tuna sirip kuning sebagian besar didistribusikan dalam termoklin di laut lepas Samudra Hindia.

Gambar 7 menunjukkan bahwa pukat cincin dengan mesh size 3,81 cm dapat menangkap ikan cakalang dengan kisaran panjang antara 27-52,5 $\mathrm{cm}$ dan pada mesh size 4,46 cm dengan ukuran antara $27-67 \mathrm{~cm}$. Dimana nilai Lc ikan cakalang yang tertangkap pada mesh size $3,81 \mathrm{~cm}$ adalah $42 \mathrm{~cm}$ dan mesh size 4,46 $\mathrm{cm}$ adalah $47 \mathrm{~cm}$ pada kedalamn berkisar antara 50120 meter.

Hasil analisis menghasilkan persamaan regresi antara antara panjang ikan (fork leng) dan titik tengah selang kelas lingkar tubuh ikan pada insang (girth opercular/go) (nilai a =intercept, $\mathrm{b}=$ slope) yang tertangap yaitu $Y=0,611 \mathrm{x}-2,758$ (Gambar 8), dengan nilai $\tilde{a}^{2}=0,922$. Persamaan menunjukkan bahwa setiap penambahan panjang ikan cakalang sebesar 1 
cm akan meningkatkan nilai Ln (selektivitas terhadap panjang ikan) sebesar 0,611. Sehingga koefisien korelasinya (ã) sebesar 0,922 yang berarti mempunyai hubungan yang erat sebesar 92,2\%.

Hasil penelitian Nugraha (2010) bahwa ukuran pertama kali tertangkap (Lc) ikan cakalang dengan huhate di perairan Laut Banda dengan kisaran panjang cagak (FL) antara 30-78 cmFL dan kisaran bobot antara
600-4300 g. Wade (1950) dalam Wild \& Hampton (1994). Ukuran pertama kali matang gonad ikan cakalang (length at first maturity) di perairan Philipina pada panjang 40,9 cmFL. Udupa (1986), Norungee \& Kawol (2011), Indian Ocean Tuna Commission (IOTC) (2013), bahwa ukuran pertama kali matang gonad cakalang di Samudera Hindia adalah $42,9 \mathrm{~cm}$ dengan kisaran antara 41,6 - 44,3 cm.

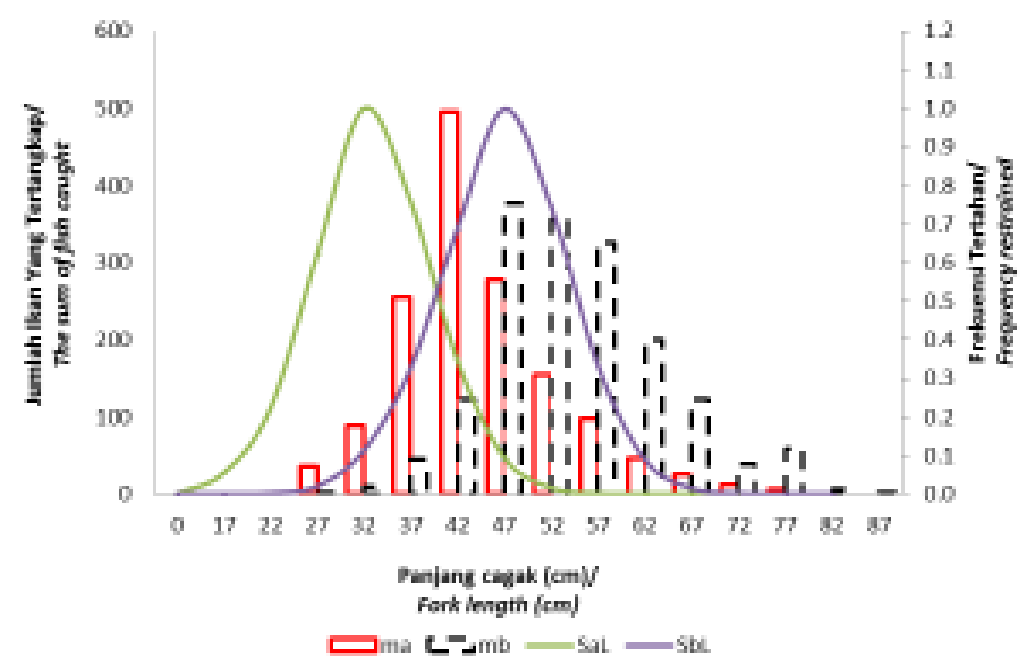

Gambar 7. Kurva selektivitas ikan cakalang pada pukat cincin dengan ukuran mata jaring 3,81 cm dan $4,46 \mathrm{~cm}$.

Figure 7. Selectivity curve of skipjack tuna caught by purse seine with mesh size 3,81 and 4,46 cm.

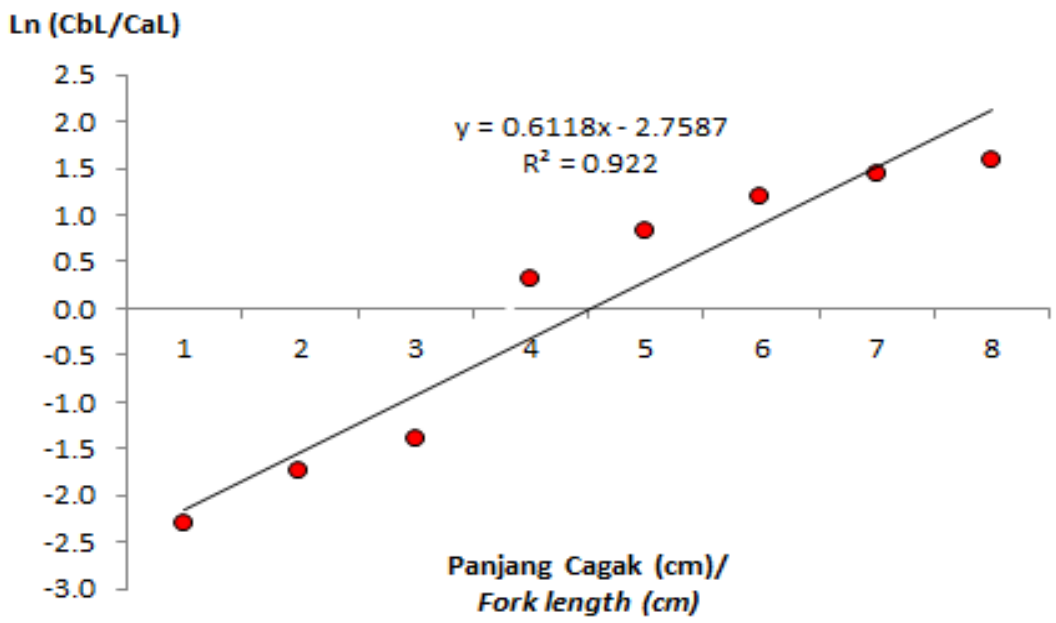

Gambar 8. Regresi dari $\mathrm{L}_{\mathrm{n}}\left(\mathrm{C}_{\mathrm{bL}} / \mathrm{C}_{\mathrm{aL}}\right)$ terhadap panjang ikan cakalang.

Figure 8. Regression betwen $\mathrm{L}_{\mathrm{n}}\left(\mathrm{C}_{\mathrm{bL}} / \mathrm{C}_{\mathrm{aL}}\right)$ and length of skipjack tuna.

Gambar 9 menunjukkan bahwa pukat cincin dengan mesh size 3,81 cm dapat menangkap ikan layang dengan kisaran panjang antara 17,5-27,5 cm dan pada mesh size 4,46 cm dengan ukuran antara 23,5-35,5 $\mathrm{cm}$. Dimana nilai Lc ikan layang yang tertangkap pada mesh size 3,81 cm adalah 23,5 cm dan mesh size 4,46 $\mathrm{cm}$ adalah 29,5 cm. 
Berdasarkan data tersebut menghasilkan persamaan regresi antara panjang ikan (fork leng) dan titik tengah selang kelas lingkar tubuh ikan pada insang (girth opercular/go) (nilai a $=$ intercept, $\mathrm{b}=$ slope) yang tertangap yaitu $Y=1,358 \mathrm{x}-4,241$ (Gambar 10), dengan nilai $\tilde{a}^{2}=0,954$. Persamaan menunjukkan bahwa setiap penambahan panjang ikan madidihang sebesar $1 \mathrm{~cm}$ akan meningkatkan nilai Ln (selektivitas terhadap panjang ikan) sebesar 1,36. Sehingga koefisien korelasinya (ã) sebesar 0,954 yang berarti mempunyai hubungan yang erat sebesar $95,4 \%$.

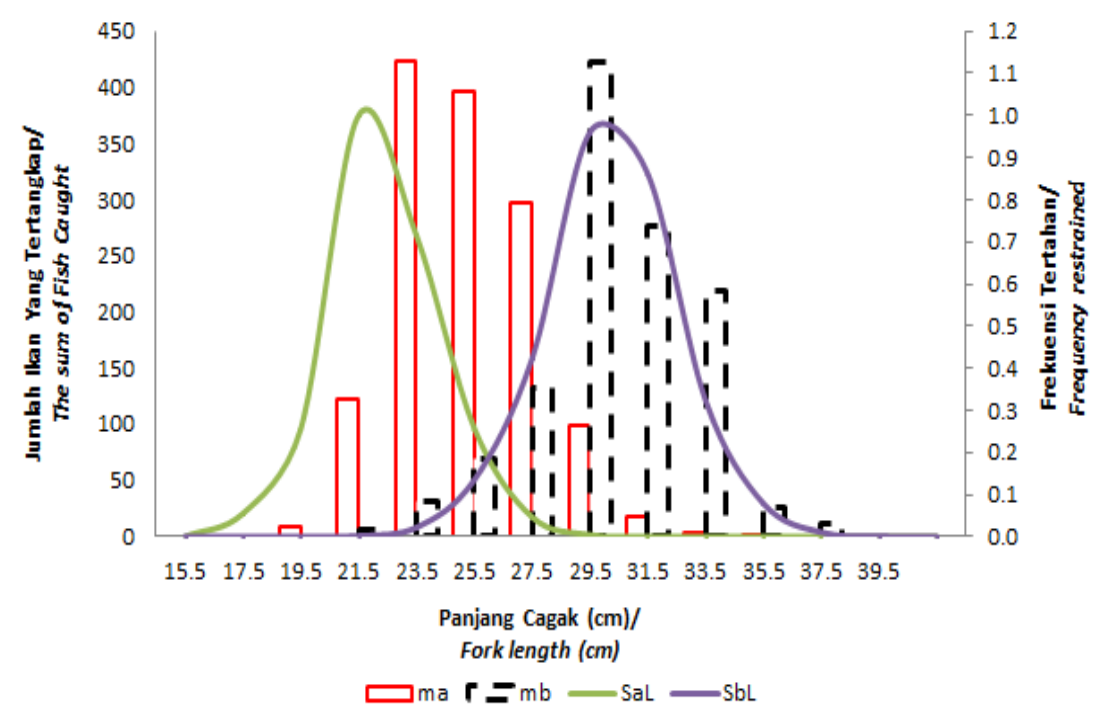

Gambar 9. Kurva selektivitas ikan layang pada pukat cincin dengan ukuran mata jaring 3,81 cm dan $4,46 \mathrm{~cm}$.

Figure 9. Selectivity curve of mackerel scad caught by purse seine with mesh size 3,81 and $4,46 \mathrm{~cm}$.

\section{$\operatorname{Ln}(\mathrm{CbL} / \mathrm{CaL})$}

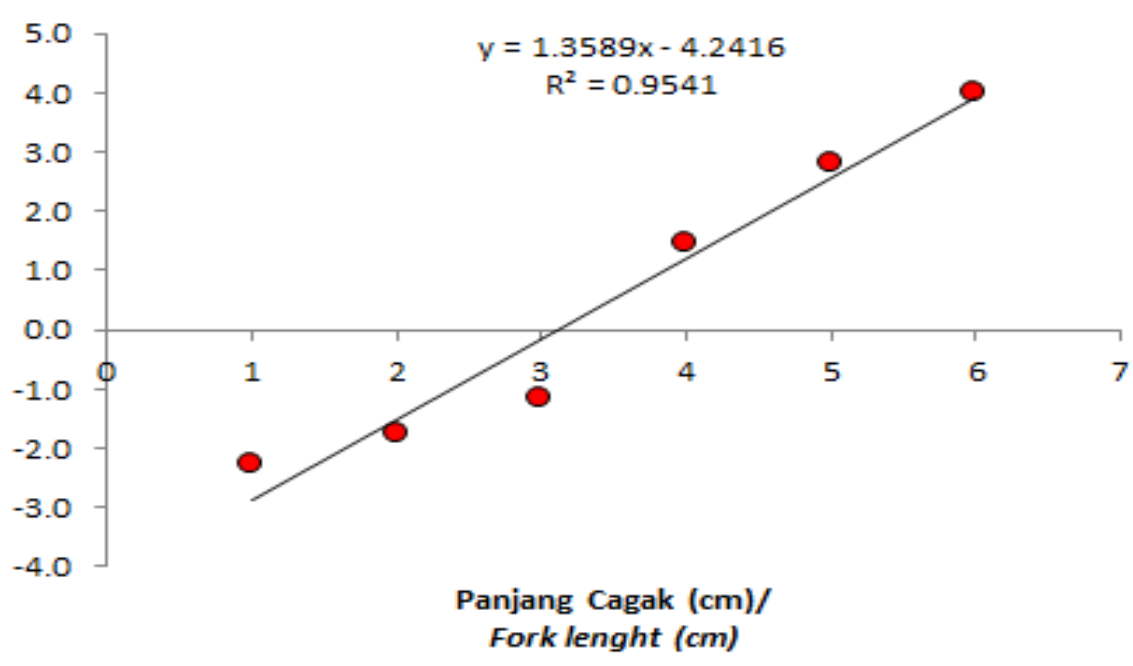

Gambar 10. Kurva regresi dari $\mathrm{L}_{\mathrm{n}}\left(\mathrm{C}_{\mathrm{bL}} / \mathrm{C}_{\mathrm{aL}}\right)$ terhadap panjang ikan layang.

Figure 10. Regression curve between $\mathrm{L}_{\mathrm{n}}\left(\mathrm{C}_{\mathrm{bl}} / \mathrm{C}_{\mathrm{aL}}\right)$ and length of mackerel scad.

Hariati (2011) bahwa panjang asimptotik (L”) Decapterus macrosoma (layang abu-abu) dan Decapterus macarellus (layang biru) di perairan Kendari memiliki panjang maksimum masing-masing 34 dan
$34,7 \mathrm{~cm} \mathrm{Tl}$. Sedangkan di perairan Sibolga tahun 2004 Lc layang biru sebesar $22 \mathrm{cmFL}$ (Hariati et al., 2011). Di perairan Teluk Ambon dan perairan Laut Banda pada tahun 1996 diperoleh nilai (L') yang tidak jauh berbeda. 
Layang abu-abu yang tertangkap di perairan Natuna dan Anambas (Hariati \& Pralampita, 2008); perairan Tawi-Tawi (Aripin \& Showers, 2000); dan perairan Teluk Honda; (Ramos et al., 2003) Filipina, perairan Karnabha di India; (Rohit \& Shanbhogue, 2005) nilai (L”) lebih rendah $(23 \mathrm{~cm} \mathrm{Tl})$. Perairan Teluk Tomini (BRPL, 2005) yang letaknya relatif dekat; sedangkan (L”) ikan layang biru di perairan Sri Langka (Dayaratne, 1997), Samudera Hindia bernilai lebih tinggi.

Sebaran ikan pelagis kecil dan besar yang tertangkap berbeda, dimana ikan pelagis kecil menyebar pada kisaran 0-50 meter, pelagis besar 60200 meter dan suhu $28,70^{\circ} \mathrm{C}-31,10^{\circ} \mathrm{C}$ (Suwarso \& Hariati 2003). Pranata (2013) dengan rawai tuna di Samudera Hindia bahwa ikan tuna albakora, madidihang, marlin hitam, marlin puith, gindara, bawal bulat dan lemadang dengan kisaran panjang 50-100 $\mathrm{cm}$ tertangkap pada pancin nomor 1 dan 2 dengan kedalaman 64-84 meter dan 110-130 meter, tuna mata besar kisaran panjang 100-150 cm tertangkap pada pancing nomor 4 dan 9 dengan kedalaman 185-205 meter. Kedalaman mata pancing tersebut berdasarkan rumus Yoshihara (1951) dalam Nugraha dan Triharyuni (2009). Lebih lanjut penelitian yang dilakukan Wudianto (1991) bahwa ikan yang tertangkap dengan perbedaan suhu, salinitas, strata kedalaman, dan musim yang berbeda. Dengan kisaran kedalaman 0-200 meter dengan pukat cincin menghasilkan hasil tangkapan yang berbeda pada kisaran panjang ikan tersebut.
Distribusi ikan pelagis sangat ditentukan oleh suhu, kedalaman salinitas, kecepatan arus dan faktor ekologi lainnya (Brandt 1984). Seperti diutarakan Simbolon (1996), bahwa fenomena distribusi vertikal populasi ikan di tandai dengan adanya pergerakan pola migrasi ikan, dimana ikan pada umumnya melakukan migrasi diurnal (pada siang hari) dan nokturnal (pada malam hari) secara vertikal pada strata perairan. Gafa et al. (2004), korelasi antara suhu dan kedalaman terhadap hasil tangkapan belum menunjukkan hasil tangkapan yang signifikan. Menurut Unar (1957) dalam Sumadhiharga (2009), bahwa ikan yang telah mencapai ukuran yang lebih besar cenderung berada pada lapisan air yang lebih dalam. Gambang et al. (2003) bahwa ikan pelagis kecil terdistribusi dikedalaman 15-60 meter, perbedaan kedalaman mengindikasikan oleh jenis dan kedalaman renang ikan yang berbeda tergantung dari kondisi optimum ikan tersebut. Hasil penelitian Wilson et al. (2005) bahwa ikan Bluefin tuna (Thunnus thynnus) di Teluk Meksiko atau Selat Florida (tempat pemijahan Atlantik barat dikenal) tersebar secara vertikal pada kedalaman $672 \mathrm{~m}$ dengan suhu berkisar antara 3,4 hingga $28,7^{\circ} \mathrm{C}$. Dimana kedalaman berenang secara signifikan berkorelasi dengan lokasi, musim, kelas ukuran, waktu hari, dan fase bulan. Laevastu dan Hayes (1981) bahwa penentuan batas penyebaran secara vertikal ikan sangat penting untuk diketahui dalam penentuan kedalaman alat tangkap saat pengoperasian dengan penyesuaian terhadap kedalaman renang ikan (swimming layer) dan suhu perairan Tabel 2.

Tabel 2. Kisaran lapisan renang ikan dan suhu perairan pelagis besar di Samudera Hindia dan Pasifik Table 2. Swimming layer of fish and the temperature of large fish the Indian Ocean and Pacific

\begin{tabular}{|c|c|c|c|c|c|}
\hline \multirow{3}{*}{ Jenis ikan } & \multicolumn{4}{|c|}{ Kisaran suhu perairan $\left({ }^{\circ} \mathrm{C}\right)$ untuk } & \multirow{3}{*}{$\begin{array}{c}\text { Lapisan } \\
\text { Renang } \\
\text { (m) }\end{array}$} \\
\hline & \multicolumn{2}{|c|}{ Habitat } & \multicolumn{2}{|c|}{ Daerah Penangkapan } & \\
\hline & Penyebaran & Optimum & Penyebaran & Optimum & \\
\hline Cakalang (Katsuwanus pelamis) & $17-28$ & $20-24$ & $19-23$ & $16-22$ & $0-40$ \\
\hline Madidihang (Thunnus albacares) & $18-23$ & $20-28$ & $20-28$ & $21-24$ & $0-200$ \\
\hline Tuna Mata Besar (Thunnus obesus) & $11-28$ & $17-23$ & $18-23$ & - & $50-400$ \\
\hline Albakora (Thunnus alalunga) & $14-23$ & $14-22$ & $15-21$ & $15-19$ & $20-300$ \\
\hline Sirip biru selatan (Thunnus macoyii) & $12-25$ & $14-21$ & $15-22$ & - & $50-300$ \\
\hline
\end{tabular}

Laevastu \& Hayes (1981) menyebutkan pengaruh oseanografi terhadap sebaran ikan pelagis dari berbagai daerah penangkapan menunjukkan bahwa arus dan suhu merupakan parameter utama terhadap sebaran ikan pelagis. Dimana ikan pelagis sangat tergantung pada struktur vertikal suhu dan akan berenang lebih dalam jika suhu dipermukaan perairan menjadi hangat. Suwarso \& Hariati (2003) SPL untuk penyebaran ikan pelagis kecil seperti layang dan kembung berkisar antara $28,70^{\circ} \mathrm{C}-31,10^{\circ} \mathrm{C}$. Frekuensi ukuran ikan pelagis yang tertangkap dengan pukat cincin yang berbeda diduga akan mempengaruhi terhadap kisaran panjang ikan tersebut.

Hasil penelitian pukat cincin di perairan Pacitan dengan ukuran mata jaring yang berbeda terhadap distribusi ukuran ikan yang tertangkap, menunjukkan kesamaan hasil penelitian pukat cincin di Jepang oleh 
Wudianto terhadap hasil ukuran ikan madidihang yang tertangkap. Dimana distribusi ukuran ikan yang lebih besar tertangkap pada kedalaman yang lebih dalam, sedangkan ukuran ikan yang lebih kecil cenderung berada di lapisan atas. Dalam pengelolaan perikanan yang ramah lingkungan dan berkelanjutan, seharusnya alat tangkap yang digunakan seperti pukat cincin yang melakukan penangkapan ikan di Samudera Hindia Selatan Jawa, harus dibatasi ukuran mata jaring dan kedalaman jaring tersebut, karena banyaknya ikan yang belum layak tangkap, tertangkap dalam jumlah besar sekitar $85 \%$ dengan pukat cincin yang melakukan penangkapan di Samudera Hindia Selatan Jawa. Hal ini menunjukkan bahwa perikanan pukat cincin di Pacitan tidak ramah lingkungan.

\section{KESIMPULAN}

Sebaran ikan pelagis yang tertangkap pada ukuran mata jaring kantong 3,81 cm dengan dalam jaring 120 $m$ lebih kecil, dari sebaran ikan dengan ukuran mata jaring 4,46 cm dengan dalam jaring $136 \mathrm{~m}$. Ukuran rata-rata ikan madidihang pertama kali tertangkap (Lc) pada ukuran mata jaring $3,81 \mathrm{~cm}$ sebesar $39,5 \mathrm{~cm}$ dan ukuran mata jaring $4,46 \mathrm{~cm}$ dengan nilai Lc sebesar $59,5 \mathrm{~cm}$, ikan cakalang Lc $42 \mathrm{~cm}$ dengan ukuran mata jaring $3,81 \mathrm{~cm}$ dan $47 \mathrm{~cm}$ pada ukuran mata jaring $4,46 \mathrm{~cm}$, dan ikan layang dengan Lc sebesar $23,5 \mathrm{~cm}$ dengan ukuran mata jaring $3,81 \mathrm{~cm}$ dan $29,5 \mathrm{~cm}$ pada ukuran mata jaring $4,46 \mathrm{~cm}$. Ikan madidihang yang tertangkap menghasilkan persamaan regresi $Y=$ $0,697 x-2,477$ dengan nilai $\tilde{a}^{2}=0,933$, cakalang sebesar $Y=0,611 \mathrm{x}-2,758$ dengan nilai $\tilde{a}^{2}=0,922$ dan ikan layang sebesar $Y=1,358 \mathrm{x}-4,241$ dengan nilai $\tilde{a}^{2}=0,954$. Sebaran vertikal ikan layang diduga menyebar pada kisaran 0-50 meter, sedangkan ikan madidihang dan cakalang menyebar pada kedalaman antara 60-200 meter.

\section{PERSANTUNAN}

Tulisan ini merupakan kontribusi dari kegiatan penelitian yang dilakukan Balai Penelitian Perikanan Laut, dengan judul "Pengkajian Kapasitas Penangkapan Pancing Tonda, Pukat Cincin dan Rawai Tuna Di Samudera Hindia Selatan Jawa (WPP 573) dan Barat Sumatera (WPP 572)", Penulis mengucapkan terima kasih kepada Kepala Balai Penelitian Perikanan Laut yang telah memberi kesempatan penulis untuk terlibat di dalam kegiatan.

\section{DAFTAR PUSTAKA}

Anggrainy. L. (1991). Estimasi Potensi Cakalang Berdasarkan Parameter Biologi di Perairan Kepulauan Bacan Kabupaten Maluku Utara. Makasar 45 hal.
Aripin, I. E., \& Showers, P. A. T. (2000). Population parameters of small pelagic $f$ Vol. 23 ishes caught of Tawi-tawi. Philippines. Naga. 4: 21-26.

Bahar, S., \& Priyanto, R. (1987). Telaah mengenal panjang cagak ikan cakalang (katsuwonus pelamis) yang tertangkap di Indonesia pada tahun 1985. Jurnal Penelitian Perikanan Laut No. 43 Tahun 1987. Balai Penelitian Perikanan Laut. Jakarta. 41: 11-17

Balai Riset Perikanan Laut. (2005). Teluk Tomini: Ekologi, Potensi Sumber Daya, Profil Perikanan, Dan Biologi Beberapa Jenis Ikan Ekonomis Penting. Balai Riset Perikanan Laut. Pusat Riset Perikanan Tangkap. Bada Riset Kelautan dan Perikanan. 114 $\mathrm{pp}$

Baso, H. (2013). Kajian Biologi Populasi ikan Cakalang (Katsuwanus pelamis) di Perairan Luwu Teluk Bone. Tesis, PPS UnHas. Makasar 123 hal.

Block, B.A., \& Stevens E.D. (2001). Tuna Physiology, Ecology, and Evolution. California (US): Academic press.

Brata, A., Novianto. D., \& Bahtiar, A. (2011). Sebaran Ikan Tuna Berdasarkan Suhu dan Kedalam di RSamudera Hindia. Jurnal Ilmu Kelautan UNDIP. Vol 16 (3): p. 165-170.

Collete, B.B., \& Nauen, C.E. (1983). FAO species catalogue. Scombrids of the world. An annotated and illustrated catalogue of tunas, mackerels, bonitos and related species known to date. FAO Fish. Synops. (125). 2:137p.

Dayaratne, P. (1997). Review of small pelagic fishes of Sri Lanka. In Devaraj, M. \& P. Martosubroto (Eds.) Small pelagic fishes in Asia-Pasific region. Proceeding of the APFIC Working Party on Marine Fishes. 1st Session 13-15 May 1997. Bangkok. Thailand. R. A. P. Publication 1997/31. 300-336.

FAO. (2010). Biological characteristics of tuna. Text by Michel Goujon and Jacek Majkowski. In: FAO Fisheries and Aquaculture Department. Available from: http:/www.fao.org/fishery/topic/16082/en . Accessed Feb 24, 2017.

Fridman, A.L., \& Carrothers, P.J.G. (1986). Calculation for Fishing Gear Design .FAa-Fishing News Books, Ltd, London. hal: 237-266

Furukawa, S., Fujioka, K., Fukuda, H., Suzuki, N., Tei, Y., \& Ohshimo, S. (2017). Archival tagging reveals swimming depth and ambient and peritoneal cavity temperature in age-0 Pacific bluefin tuna, Thunnus orientalis, off the southern coast of Japan. Environmental Biology of Fishes. Vol (100): pp 3548

Gambang, A.C., Rajali, H.B., \& Awang. D. (2003). Overview of Biology and Explotation of the Small Pelagic Fish Resources of the EEZ of Sarawak, 
Malaysia. Fisheries Research Instituite Malaysia Serawak Bintawa, Kucing. Malaysia. http:// www.fri.gov.my/friswak/publication/pelagic.pdf.

Gafa, B., Sufendrata, T., \& Uktolseja, J.C.B. (1987). Penandaan Ikan Cakalang dan Madidihang di Sekitar Rumpon Teluk Tomini-Sulawesi Utara. Jurnal Penelitian Perikanan Laut No. 43 Tahun 1987. Balai Penelitian Perikanan Laut. Jakarta. P. : 67-74

Gafa, B., Wagiyo. K,. \& Nugraha, B. (2004). Hubungan Antara Suhu dan Kedalaman Mata Pancing Terhadap Hasil Tangkapan Ikan Bigeye Tuna (Thunnus obesus) da. Pusat Riset Perikanan Tangkap. Jakarta. 63-80

Hariati, T., \& Pralampita, W. A. (2008). Analisis frekuensi panjang ikan layang dari perairan Laut Cina Selatan. Prosiding Seminar Nasional Tahunan V: Hasil Penelitian Perikanan dan Kelautan Tahun 2008. Jilid 2 Manajemen Sumber Daya Perikanan. No. Paper MS-7. Kerja Sama Jurusan Perikanan dan Kelautan. Fakultas Pertanian. Universitas Gadja Mada dengan Balai Besar Riset Pengolahan Produk dan Bioteknologi Kelautan dan Perikanan. 9 pp.

Hariati, T. (2011). Tingkat pemanfaatan ikan layang abu-abu (decapterus macrosoma) dan layang biru (decapterus macarellus) dari perairan kendari. Jurnal Penelitian Perikanan Laut. Vol 17(1): 31-40

Hariati, T., \& Amri, K. (2011). Perkembangan perikanan pelagis kecil hasil tangkapan pukat cincin dan bagan di perairan Barat Sumatera. Jurnal Penelitian Perikanan Laut. Vol 17(4): 229-235

Indian Ocean Tuna Commission. (2013). Report of the Fifteenth Session of the IOTC Working Party on Tropical Tunas. San Sebastian, Spain, 23-28 Oktober 2013. 93pp.

Laevastu, T., \& Hela. (1970). Fisheries Oceanography. Fishing News (Book) Ltd. London. 238p.

Laevastu, T., \& Hayes, M.L. (1981). Fisheries Oceanography and Ecology. Meja dan Garcia. 2003.

Loka Penelitian Perikanan Tuna. (2013). Penelitian Sumber Daya Perikanan Tuna Skala Kecil di samudera Hindia Selatan Jawa, Bali dan Nusa Tenggara. Laporan Ringkasan Penelitian Loka Penelitian Perikanan Tuna Benoa. Bali

Mardijah, S., \& Patria, M.P. (2012). Biologi reproduksi ikan madidihang (Thunnus albacares Bonnatere 1788) di Teluk Tomini. Bawal. Pusat Penelitian Pengelolaan Perikanan dan Konservasi Sumber Daya Ikan. Badan Penelitian dan Pengembangan Kelautan dan Perikanan, 4 (1) :27-34.

Martasuganda S., \& Wahju, R.I. (2011). Perhitungan selektivitas jaring insang terhadap ikan cakalang dengan pendekatan metode Matsuoka. Buletin PSP. Bogor. Institut Pertanian Bogor, 19 (3): 284292.
Mertha, I.G.S., Nurhuda, M., \& Nasrullah, A. (2006). Perkembangan perikanan tuna di Pelabuhanratu. J. Penelitian perikanan Indonesia, 12 (2):117-127.

Ming, S.L., Jun, C.X., \& XU Liu Xiong, X.L. (2004). Relationship Between Vertical Distribution of Yellowfin Tunas' (Thunnus Albacares)And The Concerned Environmental Factors In The Central Atlantic Ocean. Oceanologia et Limnologia Sinica, CNKI Journal 200090. Ocean College, Shanghai Fisheries University, Shanghai.

Nishimura. (1964). Echo Detection of Tuna: in Modern Fishing Gear of The World. FAO, 2: 382-385

Norungee, D., \& Kawol, D. (2011). Macroscopic study on some aspects of the reproductive biology of skipjack tuna (Katsuwonus pelamis) in the Western Indian Ocean.In: Proceeding Working Party on Tropical Tunas of the IOTC 2011.

Nugraha, B., \& Triharyuni, S. (2009). Pengaruh Suhu dan Kedalaman Mata pancing Rawai Tuna (Tuna Longline) Terhadap Hasil Tangkapan Tuna Di Samudera Hindia. J. Penelitian perikanan Indonesia, 15 (3): 239-247

Nugraha, B., Mardlijah, S., \& Rahmat, E. (2010). Komposisi Ukuran Cakalang (Katsuwonus Pelamis) Hasil Tangkapan Huhate Yang Didaratkan Di Tulehu, Ambon. BAWAL Widya Riset Perikanan Tangkap. Pusat Penelitian Pengelolaan Perikanan dan Konservasi Sumberdaya Ikan, 3(3):199-207

Nugroho, D. (2004). Kajian Stok Ikan Pelagis di Laut Jawa Berdasarkan Deteksi Akustik Kelautan (tidak dipublikasikan). Tesis. Program Pascasarjana. Institut Pertanian Bogor, Bogor. 134 hal.

Pranata, S.A. (2013). Kedalaman Lapisan Renang Tuna (Thunnsus sp) Yang Tertangkap Oleh Rawai Tuna di Samudera Hindia. (Skripsi). Bogor. Institut Pertanian Bogor.

Ramos, M. H., Caudelario, M. B., Mendoza, E. M., \& Gonzales, F. C. (2003). An Assessment of the Honda Bay Fisheries. Ramos. pdf. Adobe Reader. 50 pp.

Reddy, M.P. (1993). Influence of the Various Oceanographic Parameters on the Abundance of Fish Catch. Proceeding of International Workshop on Apllication of Satellite Remote Sensing for Idenifying and Forecasting Potential Fishing Zones in Developing Countries. India, 7-11 December 1993.

Rohit, P., \& Shanbhogue, S. L. (2005). Age and growth of Decapterus russelli and Decapterus macrosoma along Karnataka coast. India. Jur. Mar. Biol. Ass India. 47 (2) July-December 2005. 180-184.

Samad, F. (2002). Studi Beberapa Parameter dinamika Populasi Ikan Cakalang di Perairan Laut Flores. Makasar. 63 hal 
Santoso, H. (1999). Studi Tentang Hubungan Antara Suhu dan Kedalaman Mata Pancing Terhadap Hasil Tangkapan Tuna Longline di Perairan Selatan Pulaiau Jawa. [Tesis]. Bogor (ID): Institut Pertanian Bogor.

Simbolon, D. (1996). Pendugaan Densitas dan Penyebaran Ikan Dengan Sistem Akustik Bim Ganda di Selat Makassar (tidak dipublikasikan). Tesis. Program Pascasarjana, Institut Pertanian Bogor, Bogor. 121 hal.

Sivasubramaniam, K. (1985). The tuna fishery in the EEZs of India, Maldives and Srilangka. BOBP/WP/ 31. Colombo: 19-35.

Song, M.L., Zhang, Z., Xu, L.X., Jiang, W.X., \& Wang, J.Q. (2008). Environmental preferences of longlining for yellowfin tuna (Thunnus albacares) in the tropical high seas of the Indian Ocean. Fisheries Oceanography. Vol(17): pp 239-253

Sparred,. \& Venema. (1999) Sparre dan Venema. 1999. Introduksi Pengkajian Stok Ikan Tropis. Jakarta: Puslitbangkan. Hal $202-210$.

Sumadhiharga, O.K. (2009). Ikan Tuna. Pusat Penelitian Oseanografi. Lembaga Ilmu Pengetahuan Indonesia. Jakarta.

Suwarso,. \& Hariati, T. (2003). Biologi dan ekologi ikan pelagis kecil di pantai Utara Jawa Barat dan Selat Sunda. JPPI Edisi Sumberdaya dan Penangkapan. 9(7): 29 - 36.

Syamsuddin,. Mallawa, A., Najamuddin., \& Sudirman. (2003). Analisis Pengembangan perikanan Ikan Cakalang (Katsuwanus pelamis) Berkelanjutan di Perairan teluk Bone, kabupaten Luwu Sulawesi selatan. Makassar. 47 hal.

Trump,. \& Leggette. (1980). Optimum Swimming Speeds in Fish: The Problem of Currents. Journal of Fisheries and Aquatic Sciences. Canada. Vol. 37:7 pages. $1086-1092$
Udupa, K.S. (1986). Statistical method of estimating the size at first maturity in fishes. ICLARM, Metro Manila, Fishbyte, 4(2):8-10

Uktolseja, J.C.B. (1988). Pengaruh Kedalaman Pancing Rawai Tuna Terhadap Hasil Tangkapan Ikan Tuna. [Jurnal]. Jakarta (ID) : Lembaga Ilmu Pengetahuan Indonesia.

Wild, A., \& Hampton, J. (1994). Areview of the biology and fisheries for skipjack tuna, Katsuwonus pelamis, in the Pacific Ocean. In Interactions of pacific tuna fisheries, R. S. Shomura, J. Majkowski, and S. Langi, eds. FAO Fish. Tech. Pap.336/2:1-51

Wilson, G.S., Lutcavage, M.E., BrillM, R.W., Genovese, P., A. B. Cooper, A.B., \& Everly, A.W. (2005). Movements Of Bluefin Tuna (Thunnus thynnus) In The Northwestern Atlantic Ocean Recorded By Pop-Up Satellite Archival Tags. Marine Biology. Vol (146). Pp 409-423

Wudianto. (1991). Influence of Water Tempereture, Salinity and Transparency on the Catch of Tunas in the Vicinity of Payos at the Southeast Part of Okinawa Island. Thesis, University of the Ryukyus. Japan. p.42-52

Wyrtki, K. (1961). Physical Oceanography of the Southeast Asian waters, Naga Report Vol. 2. The University of California, Scripps Institution of Oceanography, La Jolla, California. 195p.

Yesaki, M. (1983). Observation on the biologyof yellowfin (Thunnus albacares) and skipjack (Katsuwanus pelamis) tunas in the Philipine waters. Indo-Pac. Tuna Dev. MGT.Prog., IPTP/83/WP/7 : 66p.

Zhu G, Xu L, Zhou Y \& Song L. 2008. Reproductive biology of yellowfin tuna $T$. albacares in the WestCentral Indian Ocean. Journal of Ocean University of China (EnglishEdition)7:327-332. 